43 See A.J. Hoenselaars, Images of Englishmen and Foreigners in the Drama of Shakespeare and His Contemporaries: A Study in Stage Characters and National Identity in English Renaissance Drama (London and Toronto, 1992).

44 G.K. Hunter, 'Porter, Henry (d. 1599)', The Oxford Dictionary of National Biography (Oxford, 2004) http://www.oxforddnb.com/view/article/22568 (accessed 21 Dec 2006).

45 Henslowe's Diary, 63, 242-3.

46 See Hunter, 'Porter, Henry'.

47 Lucy Munro, 'Early Modern Drama and the Repertory Approach', Research Opportunities in Renaissance Drama 42 (2003), 1-33.

\title{
Will Kemp, Shakespeare, and the Composition of Romeo and Juliet
}

'Enter Will Kemp', states Romeo and Juliet's 1599 second quarto in its uniquely specific stage direction towards the end of scene $17 .{ }^{1}$ This uniqueness makes the quarto, which editors know as Q2, a crucially important witness to the play's early performances, and to Kemp's career with Shakespeare and the Lord Chamberlain's Men. The Romeo and Juliet quartos, however, contain a number of other curious references to Kemp which act as further evidence of the working relationship between the dramatist and his company's star clown. A comparison of the play's two earliest quartos, Q1 of 1597 and Q2 of 1599 , shows the clown role to be both malleable and formative in the work's ongoing generic development. A study of Kemp in the play, through the textual anomalies which separate the printed quartos, thus provides a record of some of the transformations Romeo and Juliet underwent during the first years of its existence, as the company corrected, revised, abridged, and changed the scripts in order to capitalize on and contain the famous clown's distinctive talents.

Shakespeare wrote Romeo and Juliet in approximately 1595. Until quite recently, critics have considered the play's first printed edition, Q1, a 'bad' theatrical quarto, an approach which has tended to limit scholarly engagement with the text. ${ }^{2}$ Q2 appeared in 1599, printing a much longer version of the play. Scholars consider Q2 to be the 'good' quarto, deriving in the main from Shakespeare's 'foul papers'; despite the 1597 quarto's status as the earliest printed edition of the play, it is actually a theatrical adaptation of the longer text and thus a later version of the play as staged. ${ }^{3} \mathrm{Q} 1$ has, however, 
benefitted recently from editorial approaches that place more emphasis on staging. I confine my discussion of Kemp as the Romeo and Juliet clown to these first two quartos: the authoritative Q2, and the theatrical Q1.

The textually variant material that these extant quartos contain offers a record, albeit imperfect, of the early compositional and theatrical history of the play. Both texts also contain evidence of Kemp's performances as the main Capulet servant, Peter. Q1's evidence of Kemp appears earlier in scene 17 than Q2's: Capulet refers to one of his serving-men as 'Will' at line 41: 'Goe, goe choose dryer. Will will tell thee where thou shalt fetch them'. ${ }^{4}$ Here, the first 'Will' most likely refers to Kemp who, as we know from the later Q2's famous stage direction, played Peter. Q2's equivalent line actually gives the name Peter: 'Make haste, make haste sirra, fetch drier logs. / Call Peter, he will shew thee where they are'. These lines, along with Q2's stage direction and David Wiles's summary of Kemp's roles for Shakespeare, provide a convincing argument that Kemp played Peter in early performances of the play. ${ }^{6}$ If the dating of the composition of Romeo and Juliet at 1595 is correct, then Kemp would have been the leading comic actor for the Lord Chamberlain's Men at this time, having formed the company with Shakespeare and others in 1594.

Kemp's role as Peter, appertaining particularly to Q2's scene 17, has been the subject of a good deal of critical debate. ${ }^{7}$ Scholars have given less attention to a brief passage which appears much earlier in the play at the opening of scene 2 in both quartos, where Capulet and Paris talk of marriage to Juliet. Kemp, as Peter, is again in evidence here, though the scene does not name him. A short episode of comic interplay emerges between Kemp, cast as the bumbling and inept servant, and Capulet, before the clown has the stage to himself. If the stage direction 'Enter Will Kemp' indicates that Shakespeare wrote Q2's scene 17 so as to accommodate Kemp's musical and interpolative talents, this scene with Capulet and Paris also reveals some evidence of the relationship between the dramatist and one of his company's leading actors. More importantly, while this evidence sheds further light on Shakespeare as a working dramatist dealing with his professional peers, we also find moments where Kemp's popular style of extemporal clowning raises a number of questions about the real correlation between the page and the stage, in a creative environment where artistic decision-making does not lie in the hands of Shakespeare alone. In Shakespeare's theatre, rather, the 'author's pen' and 'actor's voice' intersect on a daily basis as a working continuum, with each necessary to, and dependent upon, the other (Troilus and 
Cressida, Prologue, 1.24). ${ }^{8}$ Within these overlapping disciplines of dramatic writing and acting, Kemp's presence in Romeo and Juliet reveals a crux in its composition, where Shakespeare's emergent tragic voice merges with the conventions of popular theatre.

Scene 2 contains some small yet significant textual variations between the two quartos. At the opening of the scene Q1 prints the stage direction 'Enter Conntie Paris, old Capulet', followed twenty-seven lines later with 'Enter Seruingman'. 'The corresponding stage direction in Q2 prints, 'Enter Capulet, Countie Paris, and the Clowne. ${ }^{10}$ The speech headings which follow in the Q2 text denote the clown simply as 'Seru.' or 'Ser.' for Servingman, and Q2 does not use the term 'Clowne' again. When the play requires Kemp again later on, in scene 17, the 'Enter Will Kemp' directive helps distinguish him from the other servants in the play and marks out his part as Peter again. Together, then, the two stage directions which refer either to the 'clowne', or to Kemp himself, reveal how Shakespeare thinks of Kemp when writing for him as Peter.

This working association can be glimpsed further in the slight variation between Q1's 'Enter Seruingman' and Q2's 'Enter Capulet, Countie Paris, and the Clowne'. Significantly, Q2 appears to maximize Kemp's role by bringing the clown on at the start of the scene before the plot requires him. While editors might interpret this entrance as a massed stage direction, a common feature of early modern dramatic texts, I suggest that, given Kemp's popularity and fame, there may be more to this stage direction than mere compositorial convention. It may well be the case that, as in scene 17, the clown's entrance here reflects Shakespeare's accommodation of Kemp. These entrances in Romeo and Juliet would not have been the first, or the last time, that a play accommodated Kemp in this way. Before the formation of the Lord Chamberlain's Men in 1594, the 1592 play A Knack to Know A Knave for the Lord Strange's Men loosely ties Kemp's part to the rest of the action as indicated in the dialogue and constructs the role in order to give Kemp the freedom to improvise if he chooses. His routines or 'merriments' were extremely popular, as the title-page of the play attests: 'With KEMPS applauded Merriments of the men of Gotham.' ${ }^{11}$ Kemp's comic stage interpolations in A Knack to Know a Knave are difficult to discern from the printed text; the title-page alone provides evidence of Kemp's 'merriments' as a marketing ploy in order to encourage readers to buy the play. In Romeo and Juliet the play's more detailed stage directions do evoke Kemp's performance or performances. 
Post Kemp's career with Shakespeare's company, Thomas Heywood's 1602 play for Worcester's Men, Marshelle Oserecke, includes the role of Cock 'the clown' for Kemp, who again appears in a self-contained opening scene, irrelevant to the plot. Many of Kemp's roles, it seems, are structured in order to allow for at least one short scene in which he speaks directly to the audience. In terms of Shakespeare's other work with Kemp, most scholars agree that the dramatist added the role of Launce in The Two Gentlemen of Verona (1593) to the existing play specifically for the actor. ${ }^{12}$ Further roles include the Clown in Titus Andronicus (1593), Bottom in A Midsummer Night's Dream (1595), Costard in Love's Labour's Lost (1594/5), and Dogberry in Much Ado About Nothing (1597/8). Both Wiles and Andrew Gurr also suggest Falstaff as a role which Shakespeare wrote for Kemp. ${ }^{13}$

If, as scholars suggest, Shakespeare's 'foul papers' are the basis for Q2, then it is the dramatist who brings on the clown at the opening of scene 2, encouraging him to repeat his conventional formula of stage antics from $A$ Knack to Know a Knave and other plays. The decision to include the clown, or Kemp, at this point - if that inclusion is authorial as opposed to compositorial - thus reflects Kemp's importance. The moment indicates the dramaturgical validity of his comic role in terms of Shakespeare's decisions for the play as a whole; Romeo and Juliet is peppered throughout with the subversive comedy of residual popular theatrical conventions of festivity, comedy that in turn challenges and destabilizes the play's tragic genre. ${ }^{14}$

At this point in the action, on to the stage walks Kemp - a famous and recognizable character from Elizabethan London - along with Shakespeare's fictional Veronese Capulet and Paris. Kemp typically plays himself in the vein of Dick Tarlton, his great clowning predecessor. This scene surely provides both Kemp and Shakespeare with a comic moment through the powerful intrusion of reality into the play world's fictional Verona. Of course, Kemp must wait until the end of the dialogue between Capulet and Paris before he has the chance to speak. As Shakespeare must have been well aware, however, even as Peter the servant, Kemp is unlikely to stand stock-still until his 'speaking' part begins at line 36 . He is, quite simply, too famous to be ignored. Furthermore, actors speak visibly as well as verbally and numerous reports emphasize the transformative and disruptive pleasure of the stage clown's initial appearance in contemporary plays. The following recollects Tarlton, the 'wonder of his time': 
As Tarlton when his head was onely seene,

The Tire-house doore and Tapistrie betweene,

Set all the multitude in such a laughter,

That could not hold for scarse an houre after. ${ }^{15}$

It is safe to assume, then, that Kemp's appearance at this point in the play causes some uproar amongst the audience, surprised and delighted at the appearance of their famous clown. For Kemp, the chance to make comic gestures to his audience consisting, for him in particular, of 'rotten-throated slaves' and 'whores, beadles [and] bawds', would have been too good an opportunity to miss. ${ }^{16}$ Capulet's rather tedious speech also gives Kemp the chance to make the type of 'damnable faces' which Hamlet later disavows in his explicit condemnation of the kind of ludic behaviour that interrupts a 'necessary question' of the play (Hamlet, 3.2.240). This mockery sits particularly well with Q2's portrayal of Capulet as a dithering old man and thus fair game for Kemp. Comic antics and visual by-play with the audience would also warm them up for the clown's speech which follows, and help recall the bawdy flavour of the play's opening carnivalesque banter between Samson and Gregory who taunt the Montagues with their 'naked weapon[s]'.17

The stage direction for Peter's entry in Q1 appears later in the scene, between lines 27 and 28, another dramatic decision which, in light of Kemp's participation, is particularly interesting. In Q2, Kemp has the opportunity to poke fun at Capulet during his speech. In Q1, however, Capulet sends for same character, and the later appearance of Kemp modifies the comedy of the scene. Rather than simply confining Kemp to a smaller proportion of stage time, which may have been the original intention behind this shorter, more fast paced text, Q1 intensifies his impact as he appears on stage in response to his 'master's' call and interrupts the show, presumably to the uproarious gratification of the audience. While Q2's adjusted stage direction, 'and the Clowne', recognizes Kemp's dramatic importance, Q1's stage direction, placed during Capulet's speech, provides for a display of Kemp's popularity and power as clown and performer. Critics now consider Q1 to be a crucially important witness to the play's early performance history, precisely in its difference from Q2, the longer and better known version of the play. One argument which conflicts most particularly with the memorial construction theory surrounding Q1 is that Shakespeare may have revised and adapted his own plays, including Romeo and Juliet. ${ }^{18}$ If, as scholars seem to agree, Q1 derives from Q2, then it is reasonable to suppose, as in Q2, that 
Q1's decision to move the clown's entry to the middle of Capulet's speech in scene 2, may have been authorial, and thus Shakespeare's own.

As John Jowett has argued, however, Q1's stage directions 'often owe their presence and their distinctive quality neither to the theatre nor to Shakespeare as dramatic author.' ${ }^{19}$ Jowett identifies Q1's annotator in the person of Henry Chettle, the former partner and assistant of John Danter, one of Q1's printers. If Chettle as opposed to Shakespeare is behind Q1's amended stage direction in scene 2, some of Q1's stage directions may indeed derive from the printing process. Chettle, however, was a dramatist in his own right, and is listed as 'best for Comedy' in Francis Meres's Palladis Tamia in $1598 .{ }^{20} \mathrm{He}$ would thus have been well placed to appreciate the value of Kemp's comedy in the play, and to adjust the scene in this way.

Whether the changes to Q1 are authorial or otherwise, the text contains other evidence of extensive abridgement, and at these points, notably, its stage directions are often condensed or massed in order to amend certain sequences of action, particularly those which are theatrically dispensible. In Q1's scene 2, Kemp's entrance is most pointedly not massed with Capulet and Paris at the opening of the scene, suggesting that the adapted text deliberately brings the clown on later in order to maximize his comic impact in this more limited version of the play.

Furthermore, despite Q1's extensive abridgement, it retains scene 2 in its entirety. Portions of Q1, as Lukas Erne points out, are close to, though 'quite a bit' shorter than, the corresponding passages in Q2, especially in scenes $1-7 .{ }^{21}$ The changes to Kemp's scene here are not substantive, suggesting the importance of this short comic scene to the entire narrative content of Romeo and Juliet. Kathleen O. Irace shows how more than 800 lines which are unique to Q2 disappear from Q1 in genuine theatrical abridgement. ${ }^{22}$ This type of performance-related amendment of scripts was normal practice and was used to excise repetitive material or action which did not advance the plot. ${ }^{23}$ As we will see, the clown's monologue which follows does not advance the action in any way; it is merely a self-contained sequence, or 'merriment', for Kemp. As such, Peter's comical speech, which both quartos retain almost in full, is clearly essential to the popular, ludic content of the play, and particularly so as concerns the servant in the guise of Kemp.

Indeed, the ensuing action in scene 2 , in both quartos, demonstrates that the purpose of the clown in this scene is to continue to exploit the play's opening comic action. The fact that Kemp is a well-known performer in the guise of a servant can only help this exploitation. Once Capulet and Paris 
exit the stage, in both texts the clown offers a monologue on his instructions regarding the guest list for the evening's revelry, printed as follows in the quartos:

Q1. Seeke them out whose names are written here, and yet I knowe not who are written here: I must to the learned to learne of them, that's as much to say, as the Taylor must meddle with his Laste, the Shoomaker with his needle, the Painter with his nets, and the Fisher with his Pensill, I must to the learned. ${ }^{24}$

Q2. Find them out whose names are written. Here it is written, that the shoomaker should meddle with his yard, and the tayler with his last, the fisher with his pensill, \& the painter with his nets. But I am sent to find those persons whose names are here writ, and can neuer find what names the writing person hath here writ (I must to the learned) in good time. ${ }^{25}$

With the stage to himself Kemp is presumably able to move to the downstage position, the open plated area, where direct interaction with the audience is possible. In this less mimetically restricted space, outside the locus of the stage, or main centre of representation, moreover, the action becomes independent of plot - more in line, as Robert Weimann suggests, with popular traditions of theatricality, and where, Vice-like, the clown can undermine the authorial script if he chooses. ${ }^{26}$

This early scene as Peter provides a space for Kemp's typical comic interpolation. Catered for in this way, the renowned clown performs with, as opposed to for, his audience, where the verbal and spatial elements of popular stagecraft combine. Not surprisingly, Kemp's monologue at this point appears comparable with ubiquitous practices of clowning. The obvious comedy of the scene stems from the fact that an illiterate servant is put in charge of a guest list which he cannot read, and his prose response, certainly at face value, appears to be improvisational as the language contains a combination of bawdy imagery and nonsensical quibbling.

The comic language here also serves to separate further the actor from his role of Peter, as the extradramatic figure of Kemp penetrates the fictional world of the play, and we can see how the well-known and successful player is clearly visible beneath Peter's veneer of servile ignorance. Kemp projects a double identity: the cover of naivety allows a form of anarchy, rooted in the popular misrule tradition of the Vice, as the player is able to step outside of 
the text, and speak directly to the audience as himself, beyond the stricture of the script and the authority of the dramatist.

Read in this light, the scene provides an obvious opportunity for Kemp to promote himself, and we can easily see how Kemp/Peter could consciously cross the boundaries of stage and yard as popular forms of connection with the audience blend with the style of autonomous professionalism and selfmarketing associated with contemporary stage practice, and, specifically, the famous clowns. ${ }^{27}$ In this moment of spatial freedom, we might conclude, Kemp sets up a complex dialectic between laughing 'at' and laughing 'with' the character he plays, perhaps at the expense of both the script and the author.

Faced with the written guest list, Kemp as the illiterate servant absurdly expresses his inability to read it. 'Here it is written', he states in Q2, in a quasibiblical style which draws deliberate attention to his list, probably a generic prop on which anything, or perhaps nothing at all, is written. Through this self-conscious and comically hyperbolical foregrounding of such theatrical artifice, Kemp, as both Peter and himself, is able to mock the idea of written authority of the highest order, drawing attention to his ability to step outside the strictures of both Capulet and the dramatist. Kemp, it would seem, as the leading clown of his day, has the power, through his very presence on stage, to challenge authorial hegemony.

Kemp's prose certainly gives the illusion of spontaneity and as such appears to affirm his improvisational talents. The speech is not, however, as ad hoc as it first appears. The passage initially seems to be a jumble of nonsense and bawdy pun, a particularly effective comic device within the auditory environment of theatre. On closer inspection, though, it reveals itself as a play on a passage from John Lyly's 1578 Euphues, the Anatomie of Wit, and thus a literary parody in the style of Bottom's biblical 'dream'. In a similar clever trick of reversal, a lowly, illiterate servant ironically burlesques the play's high-flown rhetorical content. The interesting question here, though, is why we find such material in the mouth of Peter, particularly in light of his portrayal by Kemp, the 'plain' clown. ${ }^{28}$

Lyly's didactic prose seems an odd choice for the clown figure to satirize, yet the speech does contain obvious opportunities for bawdy comic action in its talk of meddling with yards and pencils; the passage thus not only echoes the play's opening clownish repartee, but also looks towards the jig. In this way, the Lyly parody is in line with the disruptive type of vulgar improvisation expected of the stage clown. As far as the audience members 
are concerned, they are listening to Kemp, not Shakespeare. In the context of dramatic authority, however, who is responsible for the parody of Lyly? Kemp or Shakespeare? It is obviously not Peter, who cannot read.

If we consider this extract from the point of view of the author rather than the actor, a number of things become clearer. The Lylian parody here is Shakespeare attempting subtly to rein Kemp in while capitalizing on his ludic power which gives the play its inexhaustible comic edge. To quote Stephen Orgel writing on Hamlet, 'this is Shakespeare making the anti-textual textual'. ${ }^{29}$ In Hamlet, Shakespeare turns the theatrical appearance of the ghost into language, as the prince, in his newly acquired 'antic disposition', metadramatically jokes about the 'cellarage' while rushing about the stage to avoid the 'old mole' beneath (1.5.153-73). Similarly, the Romeo and Juliet monologue gives Kemp all he requires to 'play' before his audience, but the parody of Lyly gives Shakespeare control over the script, a valuable asset in the infinitely transient medium of drama.

If Shakespeare rather than Kemp is behind the Lyly allusion, then the substantive similarities between the monologue in the two quartos would also seem to affirm authorial, as opposed to extemporal, content. The original extract from Lyly, furthermore, contains an implicit hierarchical regulation of society and is thus ripe for intellectual, satirical attack: 'The shoemaker must not go above his latchet, nor the hedger meddle with anything but his bill. It is unseemly for the painter to feather a shaft, or the fletcher to handle the pencil'. ${ }^{30}$ A burlesquing of these lines seems particularly apt for caustic use in Shakespeare's 'topsy-turvy' play at this point, where Kemp, as the servant, mocks his master.

Authorial provenance at this point is also more likely if we consider Shakespeare's extensive use of Lyly throughout his work. Another play which also happens to involve Kemp, The Two Gentlemen of Verona, similarly contains Lylian material: the behaviour of Valentine and Proteus satirizes the ideals of the young Euphues in Lyly's famous work. Launce's monologue which opens act 2 scene 3 of Two Gentlemen, where Launce comically bemoans the unfaithful Crab who 'sheds not a tear nor speaks a word' (2.3.31) at their parting, anticipates one of the main motifs of the play in Proteus's abandonment of Julia.

In Kemp's speech in Romeo and Juliet, Shakespeare combines the physical presence of the clown with the complex verbal and literary allusion to Lyly. He manages to work in league with the audience and Kemp, while remaining committed to the literary content of his play. The result, to an audience 
without access to a script, or indeed to modern readers without the benefit of editorial glossing, appears to be a particularly disruptive kind of comic improvisation. As in Hamlet, which seems continually to probe the demarcation between actor and player, at this point in Romeo and Juliet, Shakespeare appears deliberately to collapse the authority between clown and dramatist, revealing his attempts both to accommodate and control Kemp's anarchic power. ${ }^{31}$ At one and the same time, he gives the audience the kind of bawdy comic banter they expect; he gives his leading clown, and one of the Chamberlain's Men's 'master-actors', the stage and the opportunity to self-promote; yet he retains a subtle control over the text while remaining within the space of Kemp's 'extemporal' acting. Kemp is able to deliver what appears to be a traditional clowning monologue, connect with the audience as himself, and extemporize, but all within the confines of the Lyly parody.

Paradoxically, then, in the space of expected extemporal clowning in Romeo and Juliet, we find the dramatic dominance of the author. Whether Kemp appears at the beginning of the Capulet/Paris dialogue or during it, however, both texts attest to the fact that the clown is potentially uncontainable on stage, despite the confines of Shakespeare's script. The only way the dramatist can control his clown is at the level of language, backed by the weighty and didactic authority of Lyly. Even Lyly's pedagogic prose, however, can be moulded to the disruptive type of bawdy improvisation expected of Kemp, in a way which suits both actor and author. Certainly, the exalted occupants of the Theatre's galleries may well have recognized the Lyly allusion. As far as the less sophisticated playgoers or 'penny stinkards' were concerned, though, they were listening to Kemp, and not Shakespeare.

The consequence of this reordering of the drama in Romeo and Juliet is the dispersal of notions of authorship within the concepts of writing and performance on Shakespeare's stage, and the shift is from seeing Shakespeare largely in terms of texts to understanding the complex dynamics between playwright, actor, and audience. From a contemporary playwriting point of view, though, by placing this type of material in the mouth of Kemp's plebeian character, Shakespeare seems self-consciously to express his experimentalism. Writing for Kemp allows him to push the generic boundaries of his tragedy, and pay court to the diverse requirements of his audiences where, as Lyly's 'Prologue' to his comedy Midas pointedly states, 'Souldiers call for Trajedies, their object is bloode', and 'Courtiers for Commedies, Their subject is love.'. Kemp's influence in Romeo and Juliet clearly works well for Shakespeare, his talents enhancing this contentious tragedy's comic appeal. Shakespeare 
uses the theatrical clown, moreover, to outdo his literary source in Arthur Brooke's long-winded poem, Romeus and Juliet, where 'Capilet', 'by his name in paper', invites his guests to the banquet. ${ }^{33}$ In his dramatic reworking of Brooke, Shakespeare seems explicitly to capitalize on the clown in this scene, giving him, ultimately, the main responsibility for launching the play's tragic mechanism. Without Capulet's illiterate servant, Romeo would never have had access to the guest list which contains Rosaline's name, and which takes him on to Capulet's party and his 'star-crossed' love. From the outset, then, Kemp's presence ensures that its comic undertones both contaminate and enhance the play's tragic content, and the resulting dramatic narrative loses its metaphysical potency. The clown satirizes this well-known fate-fuelled tragedy of love as the consequence of clumsy, blundering humanity as opposed to astrological force. Scholarship has explained the textual differences between the Romeo and Juliet quartos in a number of ways. In particular, critics have investigated Q1's variants as the result of memorial reconstruction, authorial revision, printing house intervention, and the need of Shakespeare's company to produce a more pacy version of the play. The changes to scene 2 which I discuss don't quite fit with any of these arguments, but appear to derive from an understanding of how comic scenes work on stage within the wider context of dramatic tragedy, and are therefore purely theatrical as opposed to piratical or bibliographical, or indeed literary.

Writing for an actor whose talents are rooted in minstrelsy, and who knows how to dominate a stage without the support of a plot or script, allows Shakespeare opportunities to include different modes of performance within the same dramatic structure. In Romeo and Juliet, which Frank Kermode describes as a 'strikingly original play', Shakespeare creates a unique arrangement of tragedy and comedy which seems to look towards refining and revivifying the familiar Elizabethan paradox of 'tragedy played in jest'.34

Kemp's presence in the play reveals the work as one which enacts the movable generic boundaries of comedy and tragedy, as he opens new discursive limits in Shakespeare's experimental tragic dramaturgy. The textual evidence of the changes the dramatist made to Kemp's role also seems to reveal this generic experimentalism, where he adjusts the role of the clown in order to maximize the comic content of the play, and offer the company a range of possibilities for performance in the complex and competitive conditions of the Elizabethan stage. In this way, the textually variant Romeo and Juliet quartos show how the play-texts exist in a continual state of flux between the author and his company, and thus offer an enduring record of professional 
deliberation between actors and author. This record documents the dispersal of authorial agency rather than, as traditional editorial theory would have it, a single author revising a single text. Kemp's particular presence in Romeo and Juliet articulates the enduring yet finite relationship between Shakespeare and his leading clown, as their professional negotiations over the playscript bubble beneath the variant printed texts.

Shakespeare reveals his dramatic ambitions in the Romeo and Juliet quartos. Where the variant textual evidence exposes the dramatist's desire to control Kemp, it seems also to foreground his professional predicament in writing for Kemp. Capulet's guest list, with its Lyly allusion, metadramatically shows a conflict of authority over control of the spoken (and written) word. Kemp's Peter, like Bottom who tussles with his playwright Peter Quince over his part, reveals the play's construction. In this way we can see how the clown in Romeo and Juliet articulates the play's social and aesthetic unity which, grounded in popular cultural traditions, fuses with Shakespeare's experimental dramatic expression.

Elizabeth Ford

\section{Notes}

1 [William Shakespeare], The Most Excellent and Lamentable Tragedie, of Romeo and Juliet (London, 1599) (Q2), K3v. References to this edition, and to An Excellent Conceited Tragedie of Romeo and Juliet (London, 1597) (Q1), derive from the British Library website, 'Treasures in Full: Shakespeare in Quarto' <http://www.bl.uk/ treasures/shakespeare/homepage.html>.

2 Alfred W. Pollard listed Q1 Romeo and Juliet as a 'bad' quarto in Shakespeare Folios and Quartos: A Study in the Bibliography of Shakespeare's Plays 1594-1685 (London, 1909), 64-80.

3 Q2 provides the copy-text for a third quarto (Q3) published in 1609, from which evolved a fourth quarto (Q4) in 1622, and, subsequently, the text of the First Folio edition (F1), published in 1623. For accounts of the publication history of Romeo and Juliet, see William Shakespeare, The First Quarto of 'Romeo and Juliet', ed. Lukas Erne (Cambridge, 2007), 5-7, and William Shakespeare, Romeo and Juliet, ed. Jill L. Levenson (Oxford, 2000), 103-25.

4 Shakespeare, Romeo and Juliet (Q1), I1r.

5 Shakespeare, Romeo and Juliet (Q2), K1v. 
6 David Wiles, Shakespeare's Clown: Actor and Text in the Elizabethan Playhouse (Cambridge, 1987).

7 E. Pearlman, 'Shakespeare at Work: Romeo and Juliet', English Literary Renaissance 24.2 (1994), 315-42; Wiles, Shakespeare's Clown, 88-9; Giorgio Melchiori, 'Peter, Balthasar, and Shakespeare's Art of Doubling', Modern Language Review 78 (1983), 777-92; E.A. Nungezer, A Dictionary of Actors (New York, 1968).

8 References to plays by Shakespeare other than Romeo and Juliet are to The Complete Works, Stanley Wells, Gary Taylor, John Jowett and William Montgomery (eds), 2nd edn (Oxford, 2005).

9 Shakespeare, Romeo and Juliet (Q1), B2r-B2v.

10 Shakespeare, Romeo and Juliet (Q2), B3r.

11 The title page of $A$ Knack to Know a Knave is reproduced in Pearlman, 'Shakespeare at Work', 331.

12 William Shakespeare, The Two Gentlemen of Verona, ed. Kurt Schlueter (Cambridge, 1990), 15; The Two Gentlemen of Verona, ed. Clifford Leech (London, 1969; 1972), xxi-xxxv; Wiles, Shakespeare's Clown, 73.

13 Wiles, Shakespeare's Clown, 73-4, 116-35, and Andrew Gurr, The Shakespearean Stage, 1574-1642 (Cambridge, 1970), 88.

14 Ronald Knowles, 'Carnival and Death in Romeo and Juliet', in Knowles (ed.), Shakespeare and Carnival: after Bakhtin (Basingstoke, 1998), 36-60.

15 Henry Peacham, Thalia's Banquest (1620), cited in David Mann, The Elizabethan Player (London, 1991), 56.

16 Everard Guilpin, Skialetheia (1598), Satire v, cited in Wiles, Shakespeare's Clown, 34.

17 Shakespeare, Romeo and Juliet (Q2), A3v.

18 Jay L. Halio, 'Handy-dandy: Q1/Q2 Romeo and Juliet', Jay L. Halio (ed.) Shakespeare's Romeo and Juliet: Texts, Contexts, and Interpretation, (Newark, 1995), 137.

19 John Jowett, 'Henry Chettle and the first quarto of Romeo and Juliet', Papers of the Bibliographical Society of America 92 (1998), 53-74.

20 Francis Meres, Palladis Tamia: Wits Treasury (London, 1598), 283v.

21 Shakespeare, The First Quarto of 'Romeo and Juliet', Erne (ed.), 22.

22 Kathleen O. Irace, Reforming the 'Bad' Quartos: Performance and Provenance of Six Shakespearean First Editions (London, 1994), 142.

23 Stephen Orgel, The Authentic Shakespeare and Other Problems of the Early Modern Stage (New York, 2002), 238.

24 Shakespeare, Romeo and Juliet (Q1), B2v-B3r.

25 Shakespeare, Romeo and Juliet (Q2), B3r.

26 Robert Weimann, Shakespeare and the Popular Tradition in the Theatre: Studies in the Social Dimension of Dramatic Form and Function (Baltimore, 1978), 213. 
27 Ibid, 257.

28 Throughout his career, Kemp defined his clown as a 'plain man'. See Wiles, Shakespeare's Clown, 100.

29 Orgel, The Authentic Shakespeare, 22.

30 John Lyly, Euphues, the Anatomie of Wit (1578), The Complete Works of John Lyly, R.W. Bond (ed.), 3 vols (Oxford, 1902), 1.180.

31 Robert Weimann, Author's Pen and Actor's Voice: Playing and Writing in Shakespeare's Theatre (Cambridge, 2000), 23.

32 John Lyly, Midas (1589), The Complete Works, Bond (ed.), 3.115.

33 Arthur Brooke, The Tragicall Historye of Romeus and Juliet, 1562 (1l.161-2), reproduced in William Shakespeare, Romeo and Juliet, ed. Brian Gibbons (London, 1980), 244.

34 Frank Kermode, Shakespeare's Language (London, 2001), 34.

\section{Actor, Poet, Playwright, Sharer ... Rival? Shakespeare and Heywood, 1603-4}

A person ... competing with another for the same objective, or for

superiority in the same field of activity.

A person who ... is arguably equal in quality or distinction to another.

A person having the same objective as another, an associate.

$\left(O E D \text { : 'Rival', n. }{ }^{2} 1-3 \text { : Range of definitions valid in } 1603-4\right)^{1}$

An actor, poet, playwright, and sharer. A country boy, whose family acquired a grant of arms around the turn of the century giving him the right to be addressed as 'gentleman', he came to London in the early 1590 s and gained work as an actor and a reputation as a playwright. In 1598 Francis Meres lauded him as among 'the best for comedy'. He was among those who contributed additions and alterations to Munday's Book of Sir Thomas More after Tilney censored it. In 1612 Webster praised his 'right happy and copious industry'. He was strongly influenced by Ovid and took great care over the publication of his poetry; however, he seems to have made little effort to see his plays through the press. After learning his craft through acting and writing for various groups he accepted the opportunity to become a sharer at the establishment of a prestigious new company to which he committed himself 